\title{
The Development of Handout on Palm Tree Population Structure at Rampah Manjangan Waterfall
}

\author{
Dharmono, Noor Syahdi, Muchyar \\ Biology Education Department, Faculty of Teacher and Training Education \\ Universitas Lambung Mangkurat \\ Banjarmasin, Indonesia \\ Noorsyahdu@gmail.com
}

\begin{abstract}
Development of teaching material is very necessary because it will make valid, practical, and effective teaching material. The purpose of this research was to develop the teaching material in the form of valid field research based handout on palm tree population structure in Rampah Manjangan waterfall, Loksado region, as a supplementary material on ecological plants population concepts. The type of this research was Research and Development $(R \& D)$. The measures used in this study refer to Sugiyono (2013) which have been modified into the steps of: 1) Doing the needs analysis 2) Developing the initial product 3) Validating to the experts and legibility 4) Revising Product and 5) Analyzing the data. The results showed that the validation score of teaching materials in the form of handouts feasibility aspects of the content was 88.23\% (highly valid), the presentation of the feasibility aspects was $91.66 \%$ (highly valid), feasibility aspects of language was 93.26\% (highly valid) and students test legibility was $\mathbf{8 7 . 5 0 \%}$ (excellent). From the assessment of expert validation and test of legibility students the teaching materials, the handout on palm tree population structure (Arenga pinnata Merr.) in Rampah Manjangan waterfall Loksado was highly valid and very well used as a supplementary material on ecological plants population concepts in Biology Education Department, Universitas Lambung Mangkurat, Banjarmasin.
\end{abstract}

Keywords-Development, Valid Hand Out, Palm Tree Population

\section{INTRODUCTION}

Teaching materials progress rapidly from time to time. Teaching materials were not only known in the form of a textbook or module, but also has been developed in a $\mathrm{CD}$, learning website, electronic books, instructional videos, etc. The teaching materials that have been mentioned above are claimed to be still too conventional and theoretical. In addition, there has not been developed any teaching materials that are contextual especially those that based on surround local potential such as the environment, humans, plants, and animals.

Local potential is a potential diversity of a region. Local potential can be taught to students using the teaching materials created by faculty that is based on a contextual approach so that the content of the material based on the real condition of the area or environment. Loksado is an area that has a local potential in South Kalimantan. This area can be learned and be a source of learning for students. Local potential that can be found there is Aren (palm tree). Aren itself is usually used by local communities as the fulfillment of various requirements that need to be assessed on the palm population in Loksado, precisely in Rampah Manjangan waterfall area.

Based on the students observations to ecology plant, these students found difficulty to learn the concept of population because there is a lack of examples of the specific structure of plant population in an area that can be a source of learning. As a result, the researchers realized that the teaching material is necessary to create as a supplementary material on population structure concept.

This use of teaching materials that has been developed for the course on ecological plant population material at Biology Education Department is appropriate as a supplementary material for this course uses a conceptual and contextual approach. The conceptual approach refers to the textbook provided and supported by libraries. Meanwhile, contextual approach directly goes with the learning field, measures and examines the structure of plant populations in certain areas. Therefore, combining the use of teaching materials that have been developed on the study of the structure of the population is a very good thing to do because it will add and enrich the knowledge of students about examples of the materials concept of population structure.

The above consideration encourages researchers to conduct research on the structure of Aren plant population (Arenga pinnata Merr.) in the Niagara Region Rampah Manjangan Loksado, Hulu Sungai Selatan as a creative supplementary material on ecology of plant subject.

\section{METHOD}

This type of this research was a research and development (R \& D) as modified by [11]. According to Borg and Gall, R $\& \mathrm{D}$ is a process or steps to develop new products or enhance an existing product in which all activities can be justified [8]. According to Ministry of Education and Culture [5], the implementation of research and development at the level of Tier 1 can be done through the stages of design improvement. Therefore, the modified research steps include; (1) needs 
analysis, (2) planning, (3) preliminary product design, (4) design validation, and (5) design repair.

Data validation results of teaching materials from a team of experts and students were analyzed descriptively by calculating the score validity of the results of expert validation using the formula:

$$
V S=\frac{O S V}{T S} X 100 \%
$$

$$
\begin{array}{ll}
\text { VS } & : \text { Validation Score } \\
\text { OSV } & \text { : Obtained Score Validation } \\
\text { TS } & : \text { Total Score }
\end{array}
$$

The results of the validity of a known percentage can be matched with the criteria as presented in Table I.

TABLE I. CRITERIA VALIDITY OF EXPERTS

\begin{tabular}{|c|l|l|}
\hline $\begin{array}{c}\text { Percentage } \\
(\%)\end{array}$ & Qualification & \multicolumn{1}{c|}{ Decision } \\
\hline $79,78-100$ & Highly Valid & $\begin{array}{l}\text { New product is ready to be used on } \\
\text { site for learning activities. }\end{array}$ \\
\hline $59,52-79,77$ & Valid & $\begin{array}{l}\text { The product can continue to add } \\
\text { anything less, perform certain } \\
\text { considerations which do not increase } \\
\text { too much, and not fundamental. }\end{array}$ \\
\hline $39,26-59,51$ & Lowly Valid & $\begin{array}{l}\text { It needs revision to be re-examined } \\
\text { carefully and found a weakness for } \\
\text { the refined product. }\end{array}$ \\
\hline $19,00-39,25$ & Invalid & $\begin{array}{l}\text { It needs large scale revision and } \\
\text { fundamental content of the product } \\
\text { and require more consultation. }\end{array}$ \\
\hline
\end{tabular}

Adapted from [7]

The legibility of the students test data were analyzed based on the results of questionnaire using the following formula:

$$
\mathrm{SR}(\%)=\frac{\text { Number of scores obtained }}{\text { total maximum score }} \times 100 \%
$$

\section{SR : Score responds}

A percentage that has been obtained is then converted in accordance with the following parameters:

TABLE II. PARAMETERS

\begin{tabular}{|l|l|}
\hline \multicolumn{1}{|c|}{ Score } & \multicolumn{1}{c|}{ Criterion } \\
\hline $\mathbf{7 9 . 7 8}-\mathbf{1 0 0 \%}$ & Very Good \\
\hline $\mathbf{5 9 . 5 2}-\mathbf{7 9 . 7 7 \%}$ & Good \\
\hline $\mathbf{3 9 . 2 6}-\mathbf{5 9 . 5 1 \%}$ & Fair \\
\hline $\mathbf{1 9 . 0 0 -} \mathbf{3 9 . 2 5 \%}$ & Bad \\
\hline
\end{tabular}

\section{RESULT AND DISCUSSION}

TABLE III. RESULT OF EXPERT VALIDATION AND READABILITY OF THE TEST

\begin{tabular}{|l|l|l|}
\hline \multicolumn{1}{|c|}{ Validity } & \multicolumn{1}{|c|}{$\begin{array}{c}\text { Validity } \\
\text { Final Score }\end{array}$} & \multicolumn{1}{c|}{ Specification } \\
\hline $\begin{array}{l}\text { Content } \\
\text { Feasibility aspect }\end{array}$ & $88.23 \%$ & $\begin{array}{l}\text { Highly valid (the new product is } \\
\text { ready to be used on site for } \\
\text { learning activities). }\end{array}$ \\
\hline $\begin{array}{l}\text { Presentation } \\
\text { Feasibility } \\
\text { Aspects }\end{array}$ & $91.66 \%$ & $\begin{array}{l}\text { Highly valid (the new product is } \\
\text { ready to be used on site for } \\
\text { learning activities). }\end{array}$ \\
\hline $\begin{array}{l}\text { Language } \\
\text { Assessment }\end{array}$ & $93.26 \%$ & $\begin{array}{l}\text { Highly valid (the new product is } \\
\text { ready to be used on site for } \\
\text { learning activities). }\end{array}$ \\
\hline Test readability & $87.50 \%$ & Very Good. \\
\hline
\end{tabular}

\section{A. Content Feasibility Aspect}

Based on the expert validation data, the first validity by two validators on the content feasibility aspect obtained an average score of $72.79 \%$ with a quite valid criterion and needed revision of the product. The revision was made to obtain the data such as ratings, opinions, advice, advantages and content feasibility before the handout is used by students.

According to Husamah, the expert validation is done for getting the scores, advice, advantages and disadvantages of a product which is developed. Some of the advice given on the validity of the first, namely: (1) completing and giving depth material for this type of handout as a supplementary material to enrich students knowledge, (2) providing accurate and good references based on the research at Rampah Manjangan Waterfall Region, Loksado HSS, (3) the accuracy of picture, diagrams and illustrations are expected to be made as good as possible or real because it will make students to be attracted in learning using this handout.

The second validation score was $88.23 \%$, referring to the assessment criteria by [7], the handout of palm tree population structure in Rampah Manjangan Waterfall Region, Loksado HSS has highly valid and very fit to use. The handout of palm tree population structure (ArengapinnataMerr) was declared to be valid by a final judgment of the validators. The completeness of the handout material presented includes the materials in standard competence and basic competence. The handout material was into the deep category of the material presented particularly on the concepts, definitions, and procedures in accordance with the level of education of learners as well as standard competence and basic competence.

The accuracy and definition including the definition and concept category have not made many interpretations. The accuracy of pictures, diagrams and illustrations were presented on the real condition with the data for increasing students knowledge. The analogy of example according to the facts and data (referring to the results on population at Rampah Manjangan Loksado Waterfall region) were because the students will learn about how to calculating population of plan. The assessment on complement material is very good with the complete explanation and did not make students have many interpretations. The supporting linkage of learning 
materials is complete with attractiveness of the material on the handout by containing illustrations, diagrams and pictures.

The accuracy of the concepts and definitions included in the category of concepts and definitions do not cause a lot of interpretation and in accordance with the biological sciences. The accuracy of the drawings and diagrams and illustrations are presented in accordance with reality and efficient for students. The accuracy of the facts and data presented in accordance with reality and efficiently to improve the students understanding. The accuracy of the sample is presented in accordance with reality and efficiently to improve the students understanding.

The accuracy of the references of the handout is included in the reference of good literature. Scoring of supporting material is very complete with the explanation in every paragraph. Scores item for the implementation of the handout material support learning can be done with a complete explanation and trace. The attractiveness of the material on the handout contains illustrations, diagrams and pictures. The students want to have more exploration because the handout included hypermedia.

The suitability of the material with the development of science in the handout is included in the category of actual or in accordance of the science. Score of pictures, diagrams, and illustrations is describing the real condition of the Loksado, but the comparison is not real yet. There are several examples of cases in Indonesia and few examples from the outside Indonesia. In addition, recent literature is presented in the handout including bibliography, glossary, and keywords.

\section{B. Presentation Feasibility}

The aspect of the presentation feasibility is divided into the feasibility assessment indicators, namely presentation techniques, presentation material and completeness of the presentation, referring to Asasi who assesses the presentation aspect of the product that he developed.

Validation results of the assessment score by validator 1 obtained a a score of $63.88 \%$. Referring to Pratama, the handout criterion is valid, but it still needs revision. The revision of the handout is on the material presentation, a summary and the involvement of students. Chapter 1 should be about the concept of population, population structure and description about palm tree. Chapter 2 should explain the method or technique of the research of population structure at Rampah Manjangan waterfall area, Loksado and should make the students are able to understand by themselves because the characteristic of this handout is self instructional and increasing their critical thinking. Chapter 3 contains a discussion of material about the population structure in the palm tree at Rampah Manjangan waterfall area, Loksado HSS.

The second validation after handout revision obtained a score of $91.66 \%$ validity refers to the criterion of validity of [7], the handout includes highly valid criterion. Thus, the assessment by experts has stated that the criteria are highly valid. The revised product according to [10] aims to improve the product so worthy and ready to use in the real learning.
The revised draft product is the final draft which is ready to use in learning.

The feasibility aspects rate of the presentation by Suhartanto includes several indicators or assessment item described by BSNP such as presentation techniques, supporting presentation, presentation learning, and sequence flow of thought.

Systematic consistency in the handout consists of introduction, content and cover. Sequence presentation handout was presented. In the foreword to the introduction at the beginning of the handout, the purpose of writing the handout, the teaching method including any material that should be given to the students for future teaching unit or one specific term, as well as another thing that is important for learners are presented. A summary/conclusion as a key concerned concept handout is declared with a clear and concise sentence (containing the whole purpose of the handout), enabling students to understand the overall content of the handout. Bibliography in a handout was fully written in the bibliography.

Involvement of students in the handout included in the category of interactive and participatory. The completeness of presentation rate is divided into the introduction, content part and cover part included in this category is a good thing in accordance with the assessment of validators I and II with an average value of 3 and 4 .

\section{Language Assessment}

The language assessment indicators are namely the straight forward, communicative, dialogical-interactive, effective words and use words symbols or icons. Development of teaching materials carried by [10] obtained good linguistic validation and fit to use. This is done to determine whether the language in the teaching materials are in accordance with the level of emotional intellectual and social development of students.

Based on the results of the validation on language assessment, the obtained score from the first validator was $77.88 \%$ with the criteria according to [7] is a valid criterion. Improvement (revision) on handout that was suggested by the validators 1 and 2 are on the point of accuracy and effectiveness of the sentence structure and the use of language rules. The second validation was done after revising the section suggested by the validators with a validation score obtained is $93.26 \%$ with the criterion of highly valid. The validators assessment is the accuracy of sentence structure represents the content of the message to be conveyed. The effectiveness of spoken sentences is simple and direct to the material, and the language refers to KBBI (Dictionary of Indonesian).

\section{Readability Student Test}

According to [1], the first test was done by five to ten students. This trial aims to determine the enforceability, benefits and effectiveness of the use of media in learning that needs to be done before the next test.

Based on the results of student assessment test involving legibility by five students of Biology Education department 
Universitas Lambung Mangkurat Banjarmasin who have taken the plant ecology course, referring to [9] that the test result data legibility this handout is worth with $87.50 \%$ and categorized as very good use by doing a small revision. In this test the students provide the value of the lowest value that is equal to 1 (bad) to a value of 4 high value (very good).

According to five students, the legibility test of this handout is already attractive cover design and a portrait in it. The images in this handout are interesting and appropriate to the topic. The images presented in this handout are clear or opaque. The handout language is easy to understand. The terms in the handout are easy to understand as well. The material presented in the handout already coherent, and the Plant Ecology assisted material can be understood easily in this handout.

At the students readability test, there was not any student who gave point 1 , but there were few students who gave point 2 and that the assessment was at point 4 and 6 . The minor revision was made on points 4 and 6 so that the students are expected to no longer feel that writing in a handout that includes letters, words combination, the color is not clear, then the next point about the pictures in this handout were unclear and difficult to understand after the revision it is expected to be clear and easy to understand.

\section{CONCLUSION}

The development of handout on palm tree population structure at Rampah Manjangan waterfall area, Loksado HSS as the supplementary material to the concept of population is highly valid or fit and proper to use. The score of validity on the feasibility aspect content is $88.23 \%$ with highly valid criteria, eligibility aspect of presentation is $91.66 \%$ with a validity of highly valid criteria, feasibility aspects of language is $93.26 \%$ and test the validity of students legibility is $87.50 \%$ with excellent criterion.

\section{SUGGESTIONS}

The study developed by the researchers only covered the expert testing and students legibility. Further study in the form of a small test or continuity test/class and dissemination of materials that can be used in accordance with the purpose of learning the ecology plant course material of population is required. Studying the current development has been demanded by universities to enrich the research methodology. One of which is the concept of population to add some insight and experience to independent learning (self instruction study).

\section{REFERENCES}

[1] R. Ahsyar, "Kreatif Mengembangkan Media Pembelajaran,”Jakarta: Referensi, 2012.

[2] BSNP, “Artikel tentang Kinerja BSNP Tahun 2014,”Jakarta: Badan Standar Nasional Pendidikan, 2014.

[3] Depdiknas, "Prinsip Pengembangan Bahan Ajar," Jakarta: Depdiknas, 2008.

[4] Hardiansyah, "Pengantar Ekologi Tumbuhan. Banjarmasin," Fakultas Keguruan dan Ilmu Pendidikan UNLAM.(unpublished), 2010.

[5] Kemendikbud, "Implementasi Penelitian Pengembangan (R \& D)". Direktorat Jendral Pendidikan Tinggi, Kemendikbud RI, 2012.
[6] M. D. Pranatha, "Pengaruh Sumber Belajar Terhadap Prestasi Belajar Siswa Pada Mata Pelajaran Akuntansi,'Jakarta: Universitas Pendidikan Indonesia, 2013.

[7] D. Pratiwi, Suratno, and Pujiastuti, "Pengembangan Bahan Ajar Biologi Berbasis Pendekatan SAVI (Somatic, Auditory, Visual, Intellectual) Pada Pokok Bahasan Sistem Pernapasan Kelas XI SMA dalam Meningkatkan Motivasi dan Hasil Belajar Siswa," Jember: Universitas Negeri Jember, 2014.

[8] I. G. Rasagama, "Educational Research and Development," Bandung: Politeknik Negeri Bandung, 2011.

[9] A. P. S. Rohmad and Sriyanto, "Pengembangan Lembar Kerja Siswa (LKS) Berbasis Eksplorasi, Elaborasi, dan Konfirmasi (EEK) Serta Kebencanaan Sebagai Bahan Ajar Mata Pelajaran Geografi SMA/MA di Kabupaten Rembang,"Semarang: Universitas Negeri Semarang, 2013.

[10] D. Safitri, "Pengembangan Bahan Ajar Matakuliah Biologi Sel Pada Program Studi Pendidikan Biologi di Universitas Nusantara PGRI Kediri,” Kediri: IKIP Budi Utomo Malang, 2014.

[11] Sugiyono, Metode Penelitian Pendidikan: Pendekatan Kuantitatif, Kualitatif dan R\&D," Bandung: Alfabeta, 2013. 